\title{
The accounting information system impact on micro, small, medium-sized enterprises performances in Bengkulu
}

Fachruzzaman $^{1 *}$, Rini Indriani ${ }^{2}$, Pratana Puspa Mediastuty ${ }^{3}$, Vika Fitranita ${ }^{4}$, Adista Anbarani Putri Zaman ${ }^{5}$

${ }^{1}$ Department of Accounting, Faculty of Economics and Business, Universitas Bengkulu, Bengkulu, Indonesia

${ }^{2}$ Department of Accounting, Faculty of Economics and Business, Universitas Bengkulu, Bengkulu, Indonesia

${ }^{3}$ Department of Accounting, Faculty of Economics and Business, Universitas Bengkulu, Bengkulu, Indonesia

${ }^{4}$ Department of Accounting, Faculty of Economics and Business, Universitas Bengkulu, Bengkulu, Indonesia

${ }^{5}$ Accouning Staff, Klynveld Peat Marwick Goerdeler (KPMG), Jakarta, Indonesia

*Corresponding Author(s) Email: herufeb76@gmail.com

\section{ABSTRACT}

The role of accounting information system (AIS) incorporating to firms' daily operations and management remains indisputable. This paper aims to study the effect of AIS on micro, small, medium-sized enterprises' (MSMEs) financial performance. A total of 522 datasets were gathered from structured questionnaires that were distributed to MSME owners in Bengkulu Province. Partial least squares regression (PLS) was used to build a model for predicting and evaluating the structural model of the study. Similar to the previous study, the result of the study revealed that although the majority of respondents were not implemented AIS properly, they have perceived that AIS has a positive effect on micro, small, and medium enterprises' performances. Moreover, it has also been found that the positive perception of accounting information usages is influenced by accounting resources and the application of basic accounting.

Keywords: Accounting; Information System;

Performances; Micro, Small, and Medium

Enterprises (MSMEs); Entrepreneurship
JEL Code:

M160

DOI:

10.31106/jema.v18i2.12530

Article History:

Received 2021-07-08

Reviewed 2021-07-30

Revised 2021-08-02

Accepted 2021-08-19

Licensed:

CC-BY 
The accounting information system impact on micro, small, medium-sized enterprises performances in Bengkulu by Fachruzzaman, Rini Indriani, Pratana Puspa Mediastuty, Vika Fitranita, Adista

Anbarani Putri Zaman

\section{Introduction}

Globalization increases competition, push the management team to improve business efficiency by making better judgments on business decisions, including Micro, Small, and Medium Enterprises (MSMEs). MSMEs have an important role in a country's economy (Subagyo et al., 2020; Sohilauw et al., 2020). Based on data from the Indonesian State Minister for Cooperatives Small and Medium Enterprises (2020), there are more than 55.2 million units of MSMEs that can employ around 101.7 million people. Even so, it does not always run smoothly; there are many obstacles, both internal and external, which must be faced by MSME actors. Based on the Ministry of Finance data, the internal factor becomes the main problem in MSMEs. Approximately 60-70\% of MSMEs have not had access to get finance from bank financing due to low accountability. The management has not been able to separate money for household expenses and business operations.

Wulanditya \& Aprillianita (2018) mention that many cash receipts and disbursements transactions are not recorded. Previously, Fatoki (2012) found that most micro-enterprises were not involved in financial planning and control, financial analysis, and investment appraisal; and most micro companies do not apply AIS. It impacts on cost and product prices which will certainly affect their performance. The identical finding is shown by Marriott \& Marriott (2000) in their study which found that information systems, especially AIS, were underutilized by small companies. Likewise, the research results by Ernawati et al. (2016) show that the application of information systems in MSMEs is very low. Juita (2016) found that many MSMEs actors have not or do not record and manage their financial information periodically or separately from their personal/family finances. However, most business actors understand that AIS plays an important role in evaluating the performance of MSMEs. Competition increases pressure, particularly on the management team, to improve business efficiency by making better decisions. High-quality information for decision-making requires relevant and reliable information at the right time at a reasonable cost. Ismail et al. (2012) mentioned that real-time data and reports provide considerable assistance to make the right decisions. Moreover, the study by Kharuddin et al. (2010) revealed that SMEs that adopt AIS show a significant increase in performance compared to those that do not. According to Maseko \& Manyani (2011), accounting systems provide a source of information for owners and managers of small businesses operating in any industry to use in measuring financial performance. Small business accounting practices must provide the complete and relevant 
financial information needed to improve economic decisions made by entrepreneurs. Several researchers in Indonesia provide empirical evidence that accounting information contributes to the success of MSMEs (Prastika \& Purnomo, 2014; Christian \& Rita, 2016; Nurissalmah et al., 2021). This study aims to re-investigate the effect of accounting information systems on company performance in micro, small and medium enterprises.

\section{Literature Review}

\section{Accounting Information System}

Accounting is defined as an information system because it processes data and information as input and produces output in the form of communication from accounting which can be used by (stakeholders), both internal and external, to determine financial activities and performance (Warren et al., 2017). Furthermore, Romney \& Steinbart (2012) define AIS as collecting, recording, storing, and processing data to produce information for decision-makers. These systems include people, procedures and instructions, data, software, information technology infrastructure, internal controls, and security measures. Then they are classified that there are six components of AIS which is people who use the system; procedures and instructions used to collect, process, and store data; data regarding the organization and its business activities; software used to process data; information technology infrastructure, including computers, peripheral devices, and communication network devices used in the AIS; Internal controls and security measures that store AIS data.

\section{Performances}

Performance is the result of work that can be achieved by a person or group of people in the organization, according to the authority and responsibility of each to achieve organizational goals. Performance is a series of management activities that provide an overview of the extent to which the results have been achieved in carrying out their duties and responsibilities in public accountability, both in the form of successes and failures that have occurred (Rahmanto et al., 2018). According to Permana (2017), performance is the periodic determination of the organization's operational effectiveness, its part of the organization, and its employees based on predetermined goals, standards, and criteria. So, performance is an accomplishment achieved by an organization or entity in a certain accounting period measured by comparison with various standards. Performance reflects the organization's ability to manage and allocate its resources (Lisa, 2019). Many factors affect the performance of small companies, including the influence of internal and external factors 
The accounting information system impact on micro, small, medium-sized enterprises performances in Bengkulu by Fachruzzaman, Rini Indriani, Pratana Puspa Mediastuty, Vika Fitranita, Adista

Anbarani Putri Zaman

(Wang \& Wong, 2004). Success depends on the ability to manage these two factors through analysis of environmental factors and the formation and implementation of business strategies. The internal challenges for MSMEs, especially in their development, include broad aspects in improving the quality of human resources, management capabilities, organization and technology, entrepreneurial competence, wider access to capital, transparent market information, other production input factors, and a healthy business climate that supports innovation, entrepreneurship, and business practices as well as fair competition. The performance of MSMEs can be seen from the creation of job opportunities that reflect the success or failure of a business. Thus, the greater the employment level, the greater the role of MSMEs in tackling the unemployment problem. Similarly with productivity, by increasing the workforce used, productivity is also increased. The contribution to Gross Domestic Product (GDP) can occur if MSMEs can contribute to the national economy both in domestic and foreign sales (exports). MSMEs are categorized as successful if the income consistently increases, increased sales influence it. An increase in sales also directly affects the performance of MSMEs.

\section{Accounting Information System and MSMEs Performance}

The success of a business is highly dependent on the existence of good AIS. Without such a system, it would be very difficult for a company to assess business performance, identify balance sheet reports from customers and suppliers, and predict an organization's future performance. This is in line with the opinion of Weygandt et al. (2009) which states that the success of any business will ultimately depend on the numbers generated by accounting information systems. They explained that stakeholders would rely on these numbers to make decisions and that managers would use them to evaluate organizational performance. This is valid for everyone, regardless of whether they specialize in marketing, production, management, or information technology. Accounting and financial reports are tools for communicating figures in a corporation, as they go on to say. They emphasize that if a person somehow doesn't know how to read financial statements, they will be unaware of his company's business.

Maseko \& Manyani (2011) and Christian \& Rita (2016) mention that accounting information can contribute to the success of SME business. Prastika \& Purnomo (2014); Indralesmana \& Suaryana (2014); Budiarto et al. (2015); Nurissalmah et al. (2021) prove that 
the accounting information system has a positive effect on the performance of MSMEs. So that the formulation of the hypothesis in this study is as follows.

$\mathrm{H}_{1}$ : The usage of AIS has a positive effect on MSMEs Performances.

\section{Methods}

Table 1. Item Measurements

\begin{tabular}{|c|c|c|}
\hline Variables & Code & Items \\
\hline AIS Resources & $\mathrm{O} 11$ & The familiarity of MSMEs with the accounting process. \\
\hline$(\mathrm{O} 1)^{*}$ & $\mathrm{O} 12$ & $\begin{array}{l}\text { Do you use an accountant (accounting graduate) for } \\
\text { financial records? }\end{array}$ \\
\hline \multirow[t]{2}{*}{$\begin{array}{l}\text { AIS Applied } \\
(\mathrm{O} 2)^{*}\end{array}$} & $\mathrm{O} 21$ & $\begin{array}{l}\text { There is a separation of the financial records of the entity } \\
\text { (business) with the owner (business entity). }\end{array}$ \\
\hline & $\mathrm{O} 22$ & Do SMEs prepare financial reports? \\
\hline \multirow[t]{6}{*}{$\begin{array}{l}\text { AIS Usages } \\
(\mathrm{X})\end{array}$} & $\mathrm{X} 11$ & $\begin{array}{l}\text { When purchasing raw materials or merchandise, I always } \\
\text { see the stock report of the item in the system. }\end{array}$ \\
\hline & $\mathrm{X} 12$ & $\begin{array}{l}\text { When a transaction occurs on the sale of } \\
\text { merchandise/services, I always record it in the sales record } \\
\text { or book in the system. }\end{array}$ \\
\hline & $\mathrm{X} 13$ & $\begin{array}{l}\text { When collecting accounts receivable, I always record it in } \\
\text { the accounts receivable and cash receipts book in the } \\
\text { system. }\end{array}$ \\
\hline & $\mathrm{X} 14$ & $\begin{array}{l}\text { When paying employees, I always see employee } \\
\text { performance records or reports in the system. }\end{array}$ \\
\hline & $\mathrm{X} 15$ & $\begin{array}{l}\text { When paying debts, I always look at the company's debt } \\
\text { records in the system. }\end{array}$ \\
\hline & $\mathrm{X} 16$ & $\begin{array}{l}\text { In determining the selling price of merchandise/services, I } \\
\text { always look at the system record of the production } \\
\text { price/purchase price of goods plus profits and other costs. }\end{array}$ \\
\hline \multirow[t]{7}{*}{$\begin{array}{l}\text { Performances } \\
\text { (Y) }\end{array}$} & Y11 & $\begin{array}{l}\text { Business activities are run according to the work plan as the } \\
\text { record of the system. }\end{array}$ \\
\hline & $\mathrm{Y} 12$ & $\begin{array}{l}\text { Work errors often occur, causing repetition after } \\
\text { implementing AIS. }\end{array}$ \\
\hline & Y13 & There is sales growth. \\
\hline & Y14 & There is a decrease in fixed costs after the usage of AIS. \\
\hline & Y15 & $\begin{array}{l}\text { I can anticipate the fluctuating demand precisely due to the } \\
\text { usage of AIS. }\end{array}$ \\
\hline & Y16 & Timeliness guarantee to customers. \\
\hline & Y17 & Product conformity with the specifications offered. \\
\hline
\end{tabular}

Note: *) The list of questions besides of causational item studied 
The accounting information system impact on micro, small, medium-sized enterprises performances in Bengkulu by Fachruzzaman, Rini Indriani, Pratana Puspa Mediastuty, Vika Fitranita, Adista

Anbarani Putri Zaman

This study utilized a quantitative approach. Research data in the form of primary data obtained through surveys by using the five-point Likert scale questionnaires to MSMEs and business owners in Bengkulu city of Indonesia from six regions (regency) namely Rejang Lebong, Kepahiang, Bengkulu Tengah, Bengkulu City, North Bengkulu, and Kaur. Referring to Hair et al. (2010) regarding the sample size in multivariate research, the number of representative samples taken for SEM is at least ten times the number of items. Thus, the sample that must be taken is up to 130 samples. A total of 522 MSMEs and business actors are participated and classified as respondents of the study. This number of samples considered has been met the requirement for further analysis. Moreover, the variables observed in this study were classified into independent and dependent variables. The independent variable is the usage of the accounting information system while the dependent variable is the performance of MSMEs. The data analysis was carried out using descriptive analysis and inferential analysis. Based on the primary data obtained, the frequency distribution of each solution is grouped according to the indicators and answer items. As for inferential analysis, they are starting with testing the validity and reliability, then testing the normality of the data, then doing Partial Least Squares analysis assisted by data processing software with hypothesis testing at the level of significance (p-value) $=5 \%$. In this study, the measurement of the usage of accounting information systems was developed from Fatoki (2012) while the MSME's performance measurement was modified from Christian \& Rita (2016) and Aribawa (2016). Table 1 presents the questionnaire items.

Table 2. Loading Factors

\begin{tabular}{lc}
\hline Indices & Loading Statistics \\
\hline X11 & 0.789 \\
X12 & 0.847 \\
X13 & 0.867 \\
X14 & 0.763 \\
X15 & 0.839 \\
X16 & 0.779 \\
Y13 & 0.778 \\
Y15 & 0.780 \\
Y16 & 0.690 \\
Y17 & 0.683 \\
\hline
\end{tabular}


Table 2 shows that the loading factor of the measuring indicator has a value of $>0.5$ (except for Y11, Y12, and Y14), which means that the construct has met the convergent validity test because the loading factor is $>0.5$. Table 2 also shows that the performance construct can be explained by the usage of the accounting information system (AIS) construct by $11.40 \%$. It is in the weak category because the R-square value of 0.114 is lower than 0.33 .

\section{Result and Discussion}

Table 3. MSMEs and Business Actors Profiles

\begin{tabular}{lccc}
\hline Questions & Answers & Amount & Total \\
\hline The familiarity of MSMEs with the accounting & Familiar & 225 & 522 \\
process. & Not Familiar & 297 & \\
Do you use an accountant (accounting graduate) & Yes & 71 & 522 \\
for financial records? & No & 451 & \\
There is a separation of the financial records of the & Separated & 88 & 522 \\
entity (business) with the owner (business entity). & Not Separated & 434 & \\
& Yes & 136 & 522 \\
Do SMEs prepare financial reports? & No & 386 & \\
\hline
\end{tabular}

Table 4. Hypotheses Testing

\begin{tabular}{lccc}
\hline Relationship & t-Statistics & p-Value & Decision \\
\hline AIS Usages (X) -> Performances (Y) & 8.059 & 0.000 & $\mathrm{H}_{1}$ Accepted \\
\hline
\end{tabular}

Table 3 shows that there are only a small number of MSMEs that are implement the accounting system, starting with the number of respondents who stated that $43 \%$ of respondents knew to account and/or recording, and those who made financial reports were $25 \%$, and those who applied the principles of business entities (principles that separate between the owner and the entity (business entity) concerning the transaction) by $17 \%$. Only $14 \%$ of MSMEs use accountants in making financial reports, and the results of unstructured interviews with several respondents are related to loan needs and/or related taxes. Thus, Table 4 indicates that the relationship between the usage of accounting information systems and MSMEs performance is positive with $\rho$ values 0.000 . It indicates that although the majority of respondents were not implemented AIS properly, they have perceived that AIS has a positive effect on micro, small, and medium enterprises' performances. Moreover, it has 
The accounting information system impact on micro, small, medium-sized enterprises performances in Bengkulu by Fachruzzaman, Rini Indriani, Pratana Puspa Mediastuty, Vika Fitranita, Adista

Anbarani Putri Zaman

also been found that the positive perception of accounting information usages is influenced by accounting resources and the application of basic accounting.

MSME actors evaluate their business performance and decisions making generally only based on the amount of money spent and money coming in, and tend not to collect, record, and store financial transaction documents that are useful for their business decisions. Some MSMEs do not have records related to transactions if there are general records concerning accounts receivable, payable, cash in, and cash out. The same thing was conveyed in the study of Maseko \& Manyani (2011) and Kharuddin et al. (2010).

MSMEs generally do not utilize the accounting information used to assess the financial performance of MSMEs, and because they generally do not make financial reports so that the preparation of MSME financial reports follows the rules of the Financial Accounting Standards for Micro, Small, and Medium Enterprises tends not to exist. A small proportion of MSMEs employ qualified accounting staff; this may be because the respondents in this study are generally in the micro and even ultra-micro category, and no MSMEs are auditing their financial statements at a registered/accredited auditor office.

The preference of MSME actors is that managing with an accounting information system tends to be unnecessary or that adding jobs is not value-added because the scale of the business is categorized as micro. However, the results of this study empirically affect the accounting information system on company performance in micro, small and medium enterprises. These results are in line with research conducted by Prastika \& Purnomo (2014) and Nurissalmah et al. (2021). Furthermore, referring to the six components presented by Romney \& Steinbart (2012), the accounting information system model in this study reveals three components; people (AIS resources), procedures (AIS applied), and data (AIS usages). These three components simultaneously affect the performance of MSMEs.

\section{Conclusion and Suggestion}

The result of the study revealed that although the majority of respondents were not implemented AIS properly, they have perceived that AIS has a positive effect on micro, small and medium enterprises' financial performances. Moreover, it has also been found that the positive perception of accounting information usages is influenced by accounting resources and the application of basic accounting. This study has limitations on the inability to access more in-depth information regarding financial management applied by MSME actors. Get respondents who want to fill out a questionnaire, let alone provide information. So that in this 
study, questionnaires were distributed through people who were close to the research team, which implies that the distribution of the questionnaires was not evenly distributed in all areas of the City/Regency Districts in Bengkulu Province. In this regard, it is advisable to conduct research with a qualitative approach and collaborate with related agencies/offices.

The theoretical implication of this research is to provide empirical evidence about the relationship between accounting information systems and performance, which is a subfield of accounting information systems studies. In practical terms, it is hoped that the results of this study are related to policies related to strengthening MSMEs, especially in Bengkulu City. The government, through its institutions, seeks to foster MSMEs, specifically the government accounting system through the Bank of Indonesia has made an application that is applied to MSMEs, but mostly this information is not yet known by MSME actors. So, it is better if there is assistance in collaboration with universities specifically for the Accounting Study Program carried out in connection with an internship in the independent campus curriculum.

\section{Acknowledgment}

The authors would like to thank the Faculty of Economics and Business, Universitas Bengkulu, Bengkulu, Indonesia, for providing financial support in this research and for respondents who filled out the questionnaire so that this research can be completed properly.

\section{References}

Aribawa, D. (2016). Pengaruh Literasi Keuangan Terhadap Kinerja dan Keberlangsungan UMKM DI Jawa Tengah. Siasat Bisnis, 20(1), 1-30. https://doi.org/10.20885/jsb.vol20.iss1.art1

Bank Indonesia. (2015). Profil Bisnis Usaha Mikro, Kecil Dan Menengah (Umkm). Bank Indonesia dan LPPI, 1-135.

Budiarto, D. S., Rahmawati, \& Prabowo, M. A. (2015). Accounting Information Systems Alignment and SMEs Performance: A Literature Review. International Journal of Management Economics and Social Sciences, 2.

Christian, A. B. G., \& Rita, M. R. (2016). Peran Penggunaan Informasi Akuntansi Dalam Pengambilan Keputusan Untuk Menunjang Keberhasilan Usaha. EBBANK, 7(2), 77-92. Ernawati, S., Asyikin, J., \& Sari, O. (2016). Penerapan Sistem Akuntansi Dasar pada Usaha Kecil Menengah di kota Banjarmasin. Jurnal Penelitian Ilmu Ekonomi WIGA, 6(2), 8191. https://doi.org/10.30741/wiga.v6i2.104

Fatoki, O. (2012). An Investigation into the Financial Management Practices of New Micro- 
The accounting information system impact on micro, small, medium-sized enterprises performances in Bengkulu by Fachruzzaman, Rini Indriani, Pratana Puspa Mediastuty, Vika Fitranita, Adista

Anbarani Putri Zaman

enterprises in South Africa. Journal of Social Sciences, 33(2), 179-188. https://doi.org/10.1080/09718923.2012.11893097

Indralesmana, K. W., \& Suaryana, I. G. . A. (2014). Pengaruh Penerapan Sistem Informasi Akuntansi Terhadap Kinerja Individu Pada Usaha Kecil dan Menengah Di Nusa Penida. E-Jurnal Akuntansi Universitas Udayana, 1, 14-26.

Ismail, N. A., Abdullah, S. N., \& Tayib, M. (2012). Computer-Based Accounting Systems: The Case of manufacturing-based Small and Medium Enterprises in the Northern Region of Peninsular Malaysia. Jurnal Teknologi, December. https://doi.org/10.11113/jt.v39.473

Juita, V. (2016). Pemanfaatan Sistem Informasi Akuntansi Pada Usaha Mikro, Kecil, Dan Menengah (Umkm) Sektor Jasa Perdagangan Di Padang, Sumatera Barat. Jurnal Riset Akuntansi Terpadu, 9(1), 120-139. https://doi.org/10.35448/jrat.v9i1.4291

Kharuddin, S., Ashhari, Z. M., \& Nassir, A. M. (2010). Information System and Firms' Performance: The Case of Malaysian Small Medium Enterprises. International Business Research, 3(4), P28. http://journal.ccsenet.org/index.php/ibr/article/view/6446

Lisa, O. (2019). The Effect of Entrepreneurial Behavior and Organizational Innovation on MSMEs Performance. JEMA: Jurnal Ilmiah Bidang Akuntansi dan Manajemen, 16(2), 160-172. http://dx.doi.org/10.31106/jema.v16i2.2709

Marriott, N., \& Marriott, P. (2000). Professional accountants and the development of a management accounting service for the small firm: Barriers and possibilities. Management Accounting Research, 11(4), 475-492. https://doi.org/10.1006/mare.2000.0142

Maseko, N., \& Manyani, O. (2011). Accounting practices of SMEs in Zimbabwe: An investigative study of record-keeping for performance measurement (A case study of Bindura). Journal of Accounting and Taxation, 3(8), 171-181. https://doi.org/10.5897/jat11.031

Minister for Cooperatives Small and Medium Enterprises. (2020). Teten Target Lima Tahun Ke Depan Sebanyak 48.000 Usaha Kecil Naik Kelas. https://www.kemenkopukm.go.id/read/teten-target-lima-tahun-ke-depan-sebanyak-48000-usaha-kecil-naik-kelas\#: :text=Setidaknya\%2C ada tiga peran UMKM,penting dalam kehidupan masyarakat kecil.\&text=Hal ini terbukti dalam data,meratakan tingkat perekonomian

Nurissalmah, A. M., Maslichah, \& M. Cholid Mawardi. (2021). Pengaruh Penerapan 
Pengetahuan Bisnis dan Penggunaan Sistem Informasi Akuntansi terhadap Kinerja Usaha (Studi Pada UMKM Kota Malang). E_Jurnal Ilmiah Riset Akuntansi, 10(07), 1324.

Permana, S. H. (2017). Strategi Peningkatan Usaha Mikro, Kecil, dan Menengah (UMKM) di Indonesia. Aspirasi: Jurnal masalah-masalah sosial, 8(1), 93-103. https://doi.org/10.46807/aspirasi.v8i1.1257

Prastika, N. E., \& Purnomo, D. E. (2014). Pengaruh Sistem Informasi Akuntansi terhadap Kinerja Perusahaan pada Usaha Mikro Kecil dan Menengah di Kota Pekalongan. Jurnal Litbang Kota Pekalongan, 7(2).

Rahmanto, B. T., Nurjanah, S., \& Darmo, I. S. (2018). Peran Komunitas Dalam Meningkatkan Kinerja Ukm (Ditinjau Dari Faktor Internal). Jurnal Riset Manajemen dan Bisnis (JRMB) Fakultas Ekonomi UNIAT, 3(1), 1-10. https://dx.doi.org/10.36226/jrmb.v3i1.80

Romney, M. B., \& Steinbart, P. J. (2012). Accounting information system 12th ed. Harlow: Pearson Education Limited.

Sohilauw, M. I., Nohong, M., \& Sylvana, A. (2020). The relationship between financial literacy, rational financing decision, and financial performance: An empirical study of small and medium enterprises in Makassar. Jurnal Pengurusan, 59(September), 1-15. https://doi.org/10.17576/pengurusan-2020-59-09

Subagyo, Kumar, V., \& Ernestivita, G. (2020). Entrepreneurial parameters and performance of MSMEs in East Java province of Indonesia. International Journal of Business Innovation and Research, 23(2), 267-282

Wang, C. K., \& Wong, P. K. (2004). Entrepreneurial interest of university students in Singapore. Technovation, 24(2), 163-172. https://doi.org/10.1016/S01664972(02)00016-0

Warren, C. S., Reeve, J. M., \& Duchac, J. (2017). Accounting. Cengage Learning.

Weygandt, J. J., Kimmel, P. D., \& Kieso, D. E. (2009). Managerial accounting: tools for business decision making. John Wiley \& Sons.

Wulanditya, P., \& Aprillianita, R. (2018). The Development of Accounting Information System Based on Excel in Helping Cv. Ladi Collection Preparing Their Financial Statement. JEMA: Jurnal Ilmiah Bidang Akuntansi Dan Manajemen, 15(01), 71. https://doi.org/10.31106/jema.v15i01.778 